\section{BMJ Paediatrics Open}

\title{
Reduction in paediatric intensive care admissions during COVID-19 lockdown in Maryland, USA
}

\author{
Ana Lia Graciano (D) , Adnan T Bhutta, Jason W Custer
}

To cite: Graciano AL, Bhutta AT, Custer JW. Reduction in paediatric intensive care admissions during COVID-19 lockdown in Maryland, USA. BMJ Paediatrics Open 2020;4:e000876. doi:10.1136/ bmjpo-2020-000876

Received 18 September 2020 Accepted 23 October 2020

\section{ABSTRACT}

As a public health measure during the COVID-19 pandemic, governments around the world instituted a variety of interventions to 'flatten the curve'. The government of Maryland instituted similar measures. We observed a striking decline in paediatric intensive care unit (PICU) admissions during that period, mostly due to a decease in respiratory infections. We believe this decline is multifactorial: less person-to-person contact, better air quality and perhaps 'fear' of going to a hospital during the pandemic. We report an analysis of our PICU admissions during the lockdown period and compared them with the same time period during the four previous years.

\section{To the Editor,}

The global COVID-19 pandemic caused by SARS-CoV-2 has led to a reduction in the number of adult patients being admitted for common conditions. ${ }^{1}$ The state of Maryland implemented a series of interventions on 5 March 2020. Public transportation was sharply curtailed, social distancing was encouraged and schools were closed for the balance of the school year. We observed a striking decline in paediatric intensive care unit (PICU) admissions during this period.

The PICU at the University of Maryland Children's Hospital (UMCH) in Baltimore is a 19-bed mixed unit that serves as a referral centre throughout the state. We examined PICU admissions between 1 March and 31
May 2020, using the UMCH database and compared them with the same time period during 2015-2019. Patients were identified by most common admitting categories.

Between 1 March and 31 May 2020, there were 101 PICU admissions, reflecting a decrease of $48.2 \%$ when compared with the same period during $2019(\mathrm{n}=195)$ and a decrease of almost $70 \%$ when compared with 2015-2018. When collated by the most frequent admitting diagnosis, the decline in total admissions was due to a decrease in respiratory illnesses. Furthermore, $87 \%$ of the respiratory admissions in 2020 occurred in March with only one respiratory admission in May in a child with chronic lung disease and ventilator dependency. Admissions associated with other common paediatric diagnoses such as congenital heart disease or diabetic ketoacidosis remained at the usual rate. During the study period, there were a total of 355 status asthmaticus admissions from which only six (1.7\%) occurred during March-May 2020. Similar trends are seen for bronchiolitis and pneumonia admissions (table 1).

Governments around the world instituted a variety of interventions to 'flatten the curve' during the pandemic. Viral respiratory tract infections are the leading cause of admissions. ${ }^{2}$ Transmission of respiratory viruses is complex and depends on many variables such
Check for updates

(C) Author(s) (or their employer(s)) 2020. Re-use permitted under CC BY-NC. No commercial re-use. See rights and permissions. Published by BMJ.

Department of Pediatrics/Critical Care, University of Maryland School of Medicine, Baltimore, Maryland, USA

Correspondence to Dr Ana Lia Graciano; agraciano@som.umaryland.edu

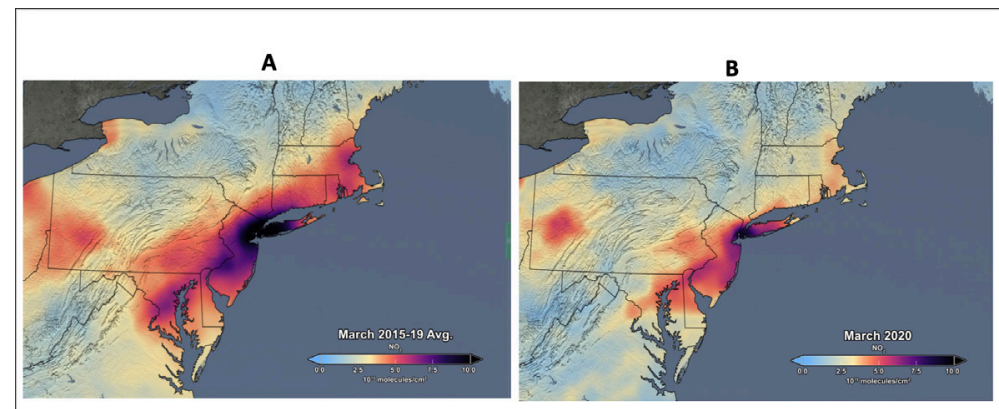

Figure 1 NASA satellite measurements revealed significant reductions in air pollution over major metropolitan areas of the northeast USA. (A) Average $\mathrm{NO}_{2}$ concentrations in March 2015-2019. (B) Average $\mathrm{NO}_{2}$ concentrations in March 2020 during the strict lockdown period. Source: NASA Aura: https://aura.gsfc.nasa.gov. 
Table 1 PICU admissions on 1 March-31 May 2015-2020

\begin{tabular}{|c|c|c|c|c|c|c|c|}
\hline & 2015 & 2016 & 2017 & 2018 & 2019 & 2020 & Total \\
\hline \multicolumn{8}{|c|}{ A: 1 March-31 May 2015-2020 (most common categories) } \\
\hline \multicolumn{8}{|c|}{ Category } \\
\hline Respiratory* & 134 & 138 & 177 & 133 & 106 & 30 & \\
\hline Cardiovascular & 48 & 51 & 34 & 47 & 57 & 56 & \\
\hline Endocrine & 16 & 12 & 12 & 14 & 8 & 7 & \\
\hline Neurological & 29 & 25 & 16 & 21 & 5 & 6 & \\
\hline Other & 81 & 73 & 70 & 60 & 19 & 2 & \\
\hline Total & 308 & 299 & 309 & 275 & 195 & 101 & \\
\hline
\end{tabular}

B: Respiratory diagnosis, 1 March-31 May 2015-2020

Respiratory diagnosis

\begin{tabular}{llrrrrrr}
\hline Status asthmaticus & 69 & 76 & 81 & 72 & 51 & 6 & 355 \\
\hline Bronchiolitis & 26 & 24 & 39 & 31 & 29 & 8 & 157 \\
\hline Pneumonia & 23 & 24 & 25 & 14 & 15 & 4 & 105 \\
\hline Croup & 5 & 5 & 8 & 1 & 4 & 0 & 23 \\
\hline Tracheitis & 4 & 3 & 9 & 7 & 3 & 3 & 29 \\
Other† & 7 & 6 & 15 & 8 & 4 & 9 & 49 \\
\hline Total & $\mathbf{1 3 4}$ & $\mathbf{1 3 8}$ & $\mathbf{1 7 7}$ & $\mathbf{1 3 3}$ & $\mathbf{1 0 6}$ & $\mathbf{3 0}$ & $\mathbf{7 1 8}$ \\
\hline
\end{tabular}

*Planned surgical procedures excluded from the analysis.

†Other: acute chest syndrome, congenital lung malformation, obstructive sleep apnoea, subglottic cyst, subglottic stenosis, aspiration pneumonitis and asphyxia.

PICU, paediatric intensive care unit.

as environmental factors, crowding and host response. Schools and day care centres are major sources of common viral infections, and children attending day care are at higher risk of having respiratory tract infections than those staying at home. ${ }^{3}$ The temporal association of reduction in PICU admissions from acute respiratory illnesses and closure of schools and day care centres is certainly clear.

An unexpected benefit of the interventions has been an improvement in air quality that could certainly be an additional factor in the dramatic reduction of paediatric asthma admissions. ${ }^{45}$ In urban areas, nitrogen dioxide $\left(\mathrm{NO}_{2}\right)$ and carbon monoxide are mainly emitted from combustion sources, particularly diesel and gasoline engines, manufacturing industry and power plants. During the lockdown period, all of these sectors had reduced operation, contributing to a decrease in environmental pollutants. ${ }^{6}$ National Aeronautics and Space Administration (NASA) satellite images show a dramatic drop in air pollution during the lockdown period compared with previous years. March 2020 showed the lowest $\mathrm{NO}_{2}$ monthly atmospheric level of any March since 2015 (figure 1).

While the human and economic costs of the COVID-19 pandemic are devastating, we are witnessing a significant decrease in the number of PICU admissions, especially those resulting from respiratory illnesses. It is unclear if this is a temporary reduction or whether this will last for a longer period as the use of virtual learning and social distancing is encouraged, and renewed emphasis on hand hygiene is incorporated into daily routines. We remain concerned though that children may not be brought in to seek appropriate medical attention due to the anxiety related to visiting a healthcare facility during the pandemic. If that is indeed the case, then it can certainly have profound short-term and long-term effects on the health of these children.

Contributors All authors contributed to the conception and design of the study. ALG and ATB contributed to data analysis and interpretation of the results. ALG drafted the manuscript. All authors contributed to the interpretation of the results. All authors had full access to the data and take responsibility for the integrity and accuracy of the analysis. All authors read, contributed to and approved the final manuscript.

Funding The authors have not declared a specific grant for this research from any funding agency in the public, commercial or not-for-profit sectors.

Map disclaimer The depiction of boundaries on this map does not imply the expression of any opinion whatsoever on the part of BMJ (or any member of its group) concerning the legal status of any country, territory, jurisdiction or area or of its authorities. This map is provided without any warranty of any kind, either express or implied.

Competing interests None declared.

Patient and public involvement Patients and/or the public were not involved in the design, or conduct, or reporting, or dissemination plans of this research.

Patient consent for publication Not required.

Provenance and peer review Not commissioned; externally peer reviewed.

Open access This is an open access article distributed in accordance with the Creative Commons Attribution Non Commercial (CC BY-NC 4.0) license, which permits others to distribute, remix, adapt, build upon this work non-commercially, and license their derivative works on different terms, provided the original work is 
properly cited, appropriate credit is given, any changes made indicated, and the use is non-commercial. See: http://creativecommons.org/licenses/by-nc/4.0/.

\section{ORCID iD}

Ana Lia Graciano http://orcid.org/0000-0001-5327-9701

\section{REFERENCES}

1 Kansagra AP, Goyal MS, Hamilton S, et al. Collateral effect of Covid-19 on stroke evaluation in the United States. N Engl J Med 2020;383:400-1.

2 Chauhan JC, Slamon NB. The impact of multiple viral respiratory infections on outcomes for critically ill children. Pediatr Crit Care Med 2017;18:e333-8.
3 Domínguez Aurrecoechea B, Fernández Francés M, Ordóñez Alonso M.Á., et al. Infectious diseases and use of health care resources in children less than 2 years-old who attend kindergarten. Anales de Pediatría 2015;83:149-59.

4 Yu H-R, Lin C-HR, Tsai J-H, et al. A multifactorial evaluation of the effects of air pollution and Meteorological factors on asthma exacerbation. Int J Environ Res Public Health 2020;17. doi:10.3390/ ijerph17114010

5 Crow SS, Undavalli C, Warner DO, et al. Epidemiology of pediatric critical illness in a population-based birth cohort in Olmsted County, Mn. Pediatr Crit Care Med 2017;18:e137-45.

6 Mahato S, Pal S, Ghosh KG. Effect of lockdown amid COVID-19 pandemic on air quality of the megacity Delhi, India. Sci Total Environ 2020;730:139086 